\title{
乳汁卜血淸卜ノ血清學的相互關係二關 スル實驗的研究
}

\author{
第 2 編，乳汁蛋白質各ふらくちおーんノ \\ 血清二對スル血淸學的關係
}

京都帝國大學醫學部微生物學敎空（主任 木村敎授）

大學院學生 醫學士 宮 川敬

Keïchi Miyakaree.

（昭和11年 4 月 18 日受村）。

\section{【内容 抄 路】}

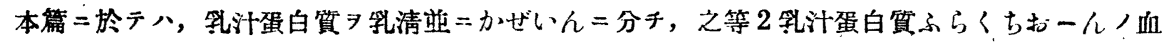

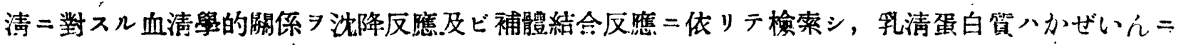
比シテ血清二極メテ近似セル蛋白質ナルョ簦明セリ。
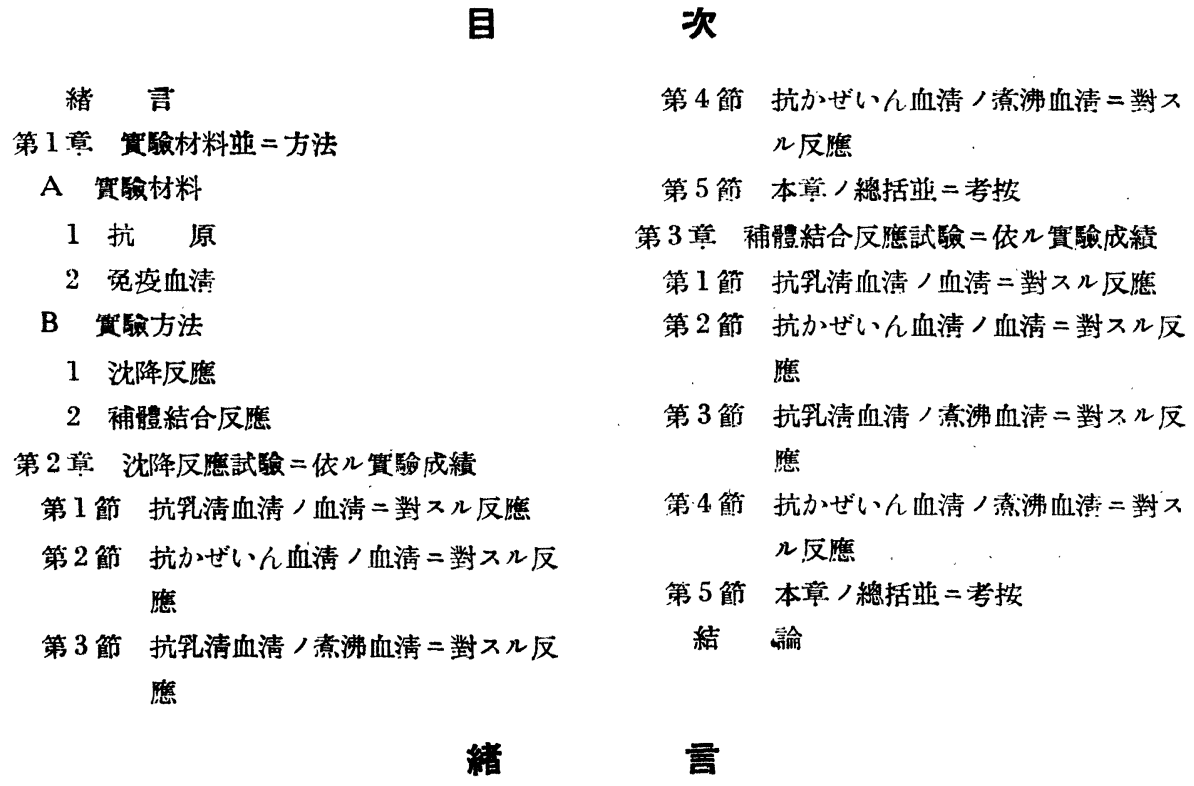

乳汁キ化學的ニかぜん及ビあるぶみん二分離シ, 之等兩者ノ血清二對スル血清舉的關係 尹研究セシ八, Hamburger(3) 尹以テ噙矩トナス可シ。氏ハ1901年新鮮ナル牛乳ヨリ弱醋酸 


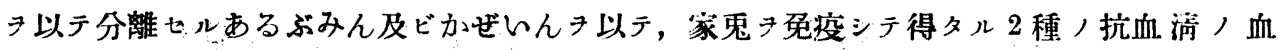

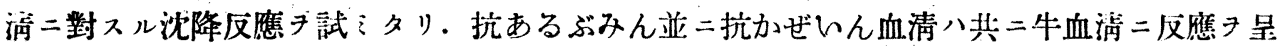
セザルモ，犢血渂二對シテ八共二反應陽性ナルタ認メ，斯クノ如ク抗かぜいん血清ガ抗ある ぶみん血清卜同程度二犢血㳯二反應スル事賽ヨリ考フルモ，血清及ビ乳汁あるぶみん八同一 物質 (identisch) 二非ザル如シト述心゙タリ.A. Klein ${ }^{(1)}$ ）抗かぜいん血清八毫モ血清二反

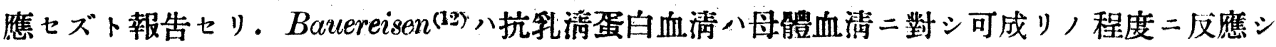

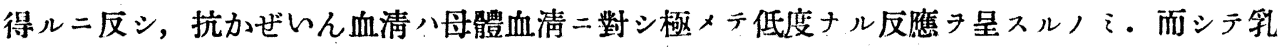
清及ビ血㳙が極メテ近似セル蛋白質ナルニモ拘ラズ，抗乳清血清が之等网者二對シ同價二反 應セザルハ，化學的物理的方法二依リテ製出セラレタル乳清蛋白質八可及的注意拂七タル ニモ拘ラズ，完全二かぜいんキ除去スル能ハズ. 從ッテかぜいんノ痕跡八抗乳清血清タシテ 血清二對シ，乳清二比シテ少シク低度二反應七シムルニ充分ナラント說明七り．長谷川(13) 八抗人乳清血清八人血清二對シ, 高度, 反應ヲ呈スルニ反シ, 抗人かぜいん血清八杼メテ低 度二反應シ得ル二過ギズ. 斯カル事賽ヨリ乳汁蛋白質二於テ血清蛋白質二近似ナルモ八, 正二乳清蛋白質ナリト隧言シ得ルトナセリ。

以上ハ主トシテ沈降反應二基ク實驗成績ニシテ, 補體結合反應二依儿實驗二關シ, Bauer (5)(14)）八抗乳清蛋白質血清, 當該及ビ近緣動物ノ血清二反應 7 呈スル事實二基キ, 乳淸蛋白 質及ビ血清蛋白質抗原八近似或八同一性狀キ有スルモノナラント思考セリ・Versell( そ)，八抗 乳清血清八該動物血清二数シ，多少ノ程度二反應シ得レドモ，抗かぜいん血清八血清卜反應 セザルタ實驗セリ。近汇(8) 二依レバ，抗かぜいん血清八，一般二血清ト反應セザルモ，抗 體ノちーてる極メテ高キ時八，正常血清二對シ微弱ナル非特異的反應き稀二現出スルト言つ。 以上諸家，所說 綜合スルニ，乳清蛋白質八血清蛋白質二對シ同一性狀キ有セザルトスル モ，少クトモ極メテ近似セル蛋白質ニシテ，之二反シかぜいん八極メテ相違七ル蛋白質ナリ トナス點二於テ, 略々一致スルラ見ル。

余八本篇二於テ, 全乳ノ血清二對スル反應八, 乳汒テ構成スル如何ナル要素二依リテ代表 七ラルルモノナリヤダ檢索セント欲シ, 乳汁蛋白質タかぜいん及ビ乳清ノ2 2 ふらくちお一ん 二分離シ, 之等 2 者, 血清二對スル關係习研究セリ。

\section{第.1童 實驗材料並二方法}

\section{A. 實 驗 材 料}

1. 抗原. 乳汁蛋白質各ふらくちお一ん抗原トシテ, 人, 牛及ビ山羊，新魴㳶ヨリ分

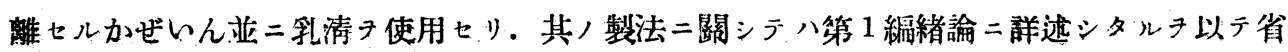
略不。 
其ノ分離二際シテハ, 可及的純粹二且化學的操作ニ依ル變質キ來サザル樣多大ノ注意キ拂 ヒタリ.

乳清及ビかぜレん溶液ハ各乳汁中二含有セラルル絕對量ヨ原液トシ，之ヨリ起算セリ。 血清抗原トシテ八, 人, 牛及ビ山羊ノ血清キ用七, 沈降反應用トシテハ生ノ谥テ使用シ, 補體結合反應用トシテハ $56^{\circ} \mathrm{C}, 30$ 分間加溫シテ非働性トナス.

2 免疫血清. 抗原/ 使用量及ビ乔疫方法等八緒論二詳述セリ.

\section{B. 實 驗 方 法}

1. 沈降反應. Uhlenhuth, 輪環法二低儿.

2. 補䚙結合反應. 抗原遞减桸釋法 用フ。

以上ノ術式二關シテ八第 1 縟緒論二詳述七り．成績判定八沈降反應二於テ八重居後 2 時間 以冈二白輪キ生ジタルモ, キ陽性トナシ, $(+)$ キ以テ表示ス. 補體結合反應二在りテハ溶血 ノ程度二從ヒ, 下記ノ符號尹以テ表記ス。
K. 完全溶血.
fk. 殆ド完全溶血
st. 强度溶血
m. 中等度溶血
w. 弱度溶血
sp. 痕跡溶血
spch. 殆ド完全溶血阻止
O. 完全溶血阻止.

\section{第 2 沈降反應試驗二依ル實驗成績}

第 1 節 抗乳清血清ノ血清二對スル反應

第 1 表 抗牛乳清血清, 各種血清二對スル沈降反應

\begin{tabular}{|c|c|c|c|c|c|c|c|c|c|c|c|}
\hline $\begin{array}{l}\text { 家鬼 } \\
\text { 番號 }\end{array}$ & 抗 原 & 50 & 100 & 200 & 4.00 & 800 & 1600 & 3200 & 6400 & 12800 & 25600 \\
\hline 33 & $\begin{array}{l}\text { 人 血 淸 } \\
\text { 牛血 湢 } \\
\text { ! 羊血淸 } \\
\text { 牛乳 清 }\end{array}$ & $\begin{array}{l}- \\
+ \\
+ \\
+\end{array}$ & $\begin{array}{l}- \\
+ \\
+ \\
+\end{array}$ & $\begin{array}{l}- \\
+ \\
+ \\
+\end{array}$ & $\begin{array}{l}- \\
+ \\
+ \\
+\end{array}$ & $\begin{array}{l}- \\
+ \\
+ \\
+\end{array}$ & $\begin{array}{l}- \\
+ \\
+ \\
+\end{array}$ & $\begin{array}{l}- \\
+ \\
+ \\
+\end{array}$ & $\begin{array}{l}- \\
+ \\
\pm \\
+\end{array}$ & $\begin{array}{l}- \\
- \\
- \\
\pm\end{array}$ & $\begin{array}{l}- \\
- \\
- \\
-\end{array}$ \\
\hline 34 & $\begin{array}{l}\text { 人 血 清 } \\
\text { 牛血 清 } \\
\text { 山羊血清 } \\
\text { 4. 乳 清 }\end{array}$ & $\begin{array}{l}- \\
+ \\
+ \\
+\end{array}$ & $\begin{array}{l}- \\
+ \\
+ \\
+\end{array}$ & $\begin{array}{l}- \\
+ \\
+ \\
+\end{array}$ & $\begin{array}{l}\dot{-} \\
+ \\
+ \\
+\end{array}$ & $\begin{array}{l}- \\
+ \\
+ \\
+\end{array}$ & $\begin{array}{l}- \\
+ \\
+ \\
+\end{array}$ & $\begin{array}{l}- \\
+ \\
+ \\
+\end{array}$ & $\begin{array}{l}- \\
+ \\
\pm \\
+\end{array}$ & $\begin{array}{l}- \\
- \\
- \\
+\end{array}$ & $\begin{array}{l}- \\
- \\
- \\
-\end{array}$ \\
\hline 35 & $\begin{array}{l}\text { 人 血 清 } \\
\text { 牛 血 清 } \\
\text { !羊血清 } \\
\text { 牛乳 清 }\end{array}$ & $\begin{array}{l}- \\
+ \\
+ \\
+\end{array}$ & $\begin{array}{l}- \\
+ \\
+ \\
+\end{array}$ & $\begin{array}{l}- \\
+ \\
+ \\
+\end{array}$ & $\begin{array}{l}- \\
+ \\
+ \\
+\end{array}$ & $\begin{array}{l}- \\
+ \\
+ \\
+\end{array}$ & $\begin{array}{l}- \\
+ \\
+ \\
+\end{array}$ & $\begin{array}{l}- \\
+ \\
+ \\
+\end{array}$ & $\begin{array}{l}- \\
+ \\
- \\
+\end{array}$ & $\begin{array}{l}- \\
+ \\
+ \\
+\end{array}$ & $\begin{array}{l}- \\
- \\
-\end{array}$ \\
\hline
\end{tabular}

第 1 表. 抗牛乳清血清ハ牛血清二對シ該乳清二對スルト略々同程度二反應习呈シ，山羊血 清ニ對シテハ僅カ二低度ナル反應 見ル。人血清ニ龂シテハ全然反應七ズ。 
第 2 表 抗山羊乳清血清ノ各種血清二對ス几沈降反應

\begin{tabular}{|c|c|c|c|c|c|c|c|c|c|c|c|}
\hline 家番鬼號 & 抗 原 & 50 & 100 & 200 & 400 & 800 & 1600 & 3200 & 6400 & 12800 & 25600 \\
\hline 70 & $\begin{array}{l}\text { 人血 清 } \\
\text { 牛血 清 } \\
\text { 山羊血清 } \\
\text { 山羊乳清 }\end{array}$ & $\begin{array}{l} \pm \\
+ \\
+ \\
+\end{array}$ & $\begin{array}{l}- \\
+ \\
+ \\
+\end{array}$ & $\begin{array}{l}- \\
+ \\
+ \\
+\end{array}$ & $\begin{array}{l}- \\
+ \\
+ \\
+\end{array}$ & $\begin{array}{l}- \\
+ \\
+ \\
+\end{array}$ & $\begin{array}{l}- \\
+ \\
+ \\
+\end{array}$ & $\begin{array}{l}- \\
+ \\
+ \\
+\end{array}$ & $\begin{array}{l}- \\
- \\
+ \\
+\end{array}$ & $\begin{array}{l}- \\
- \\
+ \\
+\end{array}$ & $\begin{array}{l}- \\
- \\
- \\
\pm\end{array}$ \\
\hline 75 & $\begin{array}{l}\text { 人 血 清 } \\
\text { 牛 血 清 } \\
\text { 山羊血清 } \\
\text { 山羊乳清 }\end{array}$ & $\begin{array}{l}- \\
+ \\
+ \\
+\end{array}$ & $\begin{array}{l}- \\
+ \\
+ \\
+\end{array}$ & $\begin{array}{l}- \\
+ \\
+ \\
+\end{array}$ & $\begin{array}{l}- \\
+ \\
+ \\
+\end{array}$ & $\begin{array}{l}- \\
+ \\
+ \\
+\end{array}$ & $\begin{array}{l}- \\
+ \\
+ \\
+\end{array}$ & $\begin{array}{l}- \\
\pm \\
+ \\
+\end{array}$ & $\begin{array}{l}- \\
- \\
+ \\
+\end{array}$ & $\begin{array}{l}- \\
- \\
- \\
+\end{array}$ & $\begin{array}{l}- \\
- \\
-\end{array}$ \\
\hline 76 & $\begin{array}{l}\text { 人 血 清 } \\
\text { 牛 血 清 } \\
\text { 山羊血清 } \\
\text { 山羊乳清 }\end{array}$ & $\begin{array}{l}- \\
+ \\
+ \\
+\end{array}$ & $\begin{array}{l}- \\
+ \\
+ \\
+\end{array}$ & $\begin{array}{l}- \\
+ \\
+ \\
+\end{array}$ & $\begin{array}{l}- \\
+ \\
+ \\
+\end{array}$ & $\begin{array}{l}- \\
+ \\
+ \\
+\end{array}$ & $\begin{array}{l}- \\
- \\
+ \\
+\end{array}$ & $\begin{array}{l}- \\
- \\
+ \\
+\end{array}$ & $\begin{array}{l}- \\
- \\
\pm \\
+\end{array}$ & $\begin{array}{l}- \\
- \\
- \\
+\end{array}$ & $\begin{array}{l}- \\
- \\
- \\
\pm\end{array}$ \\
\hline
\end{tabular}

第 2 表. 抗山羊乳清血清ハ山羊血清ニ對シテ高度二反應キ呈スルモ, 該乳清二比シテ少シ ク低度ニシテ，牛血清二對シテ八更二低度ナル反雇ヨ見ル．人血清二對シテハ名ド反應七ズ.

第 3 表 抗人乳清血清ノ各種血清二對スル沈降反應

\begin{tabular}{|c|c|c|c|c|c|c|c|c|c|c|c|c|}
\hline $\begin{array}{l}\text { 家象 } \\
\text { 番號 }\end{array}$ & $\begin{array}{ll} & \text { 稀釋倍數 } \\
\text { 抗 原 }\end{array}$ & 50 & 100 & 200 & 400 & 800 & 1600 & 3200 & 6400 & 12800 & 25600 & 51200 \\
\hline 66 & $\begin{array}{l}\text { 血 清 } \\
\text { 4 血 清 } \\
\text { 山羊血清 } \\
\text { 人乳 清 }\end{array}$ & $\begin{array}{l}+ \\
- \\
-\end{array}$ & $\begin{array}{l}+ \\
- \\
- \\
+\end{array}$ & $\begin{array}{l}+ \\
- \\
- \\
+\end{array}$ & $\begin{array}{l}+ \\
- \\
- \\
+\end{array}$ & $\begin{array}{l}+ \\
- \\
- \\
+\end{array}$ & $\begin{array}{l}+ \\
- \\
- \\
+\end{array}$ & $\begin{array}{l}+ \\
- \\
- \\
+\end{array}$ & $\begin{array}{l}+ \\
- \\
- \\
+\end{array}$ & $\begin{array}{l}+ \\
- \\
- \\
+\end{array}$ & $\begin{array}{l}- \\
- \\
- \\
+\end{array}$ & $\begin{array}{l}- \\
- \\
-\end{array}$ \\
\hline 67 & $\begin{array}{l}\text { 人 血 㴔 } \\
\text { 牛 血 清 } \\
\text { 山羊血清 } \\
\text { 人 乳 清 }\end{array}$ & $\begin{array}{l}+ \\
- \\
- \\
+\end{array}$ & $\begin{array}{l}+ \\
- \\
- \\
+\end{array}$ & $\begin{array}{l}+ \\
- \\
- \\
+\end{array}$ & $\begin{array}{l}+ \\
- \\
- \\
+\end{array}$ & $\begin{array}{l}+ \\
- \\
- \\
+\end{array}$ & $\begin{array}{l}+ \\
- \\
- \\
+\end{array}$ & $\begin{array}{l}+ \\
- \\
-\end{array}$ & $\begin{array}{l}+ \\
- \\
- \\
+\end{array}$ & $\begin{array}{l}+ \\
- \\
- \\
+\end{array}$ & $\begin{array}{l}- \\
- \\
- \\
+\end{array}$ & $\begin{array}{l}- \\
- \\
-\end{array}$ \\
\hline 69 & $\begin{array}{l}\text { 人 血 清 } \\
\text { 牛 血 清 } \\
\text { 山羊血清 } \\
\text { 人 乳 清 }\end{array}$ & $\begin{array}{l}+ \\
- \\
- \\
+\end{array}$ & $\begin{array}{l}+ \\
- \\
- \\
+\end{array}$ & $\begin{array}{l}+ \\
- \\
- \\
+\end{array}$ & $\begin{array}{l}+ \\
- \\
- \\
+\end{array}$ & $\begin{array}{l}+ \\
- \\
- \\
+\end{array}$ & $\begin{array}{l}+ \\
- \\
- \\
+\end{array}$ & $\begin{array}{l}+ \\
- \\
- \\
+\end{array}$ & $\begin{array}{l} \pm \\
- \\
- \\
+\end{array}$ & $\begin{array}{l}- \\
- \\
-\end{array}$ & $\begin{array}{l}- \\
- \\
-\end{array}$ & $\begin{array}{l}- \\
- \\
-\end{array}$ \\
\hline
\end{tabular}

第 3 表. 抗人乳清血清八人血清二對シ明カ二反應シ，ソノ反應度八人乳清二對スルト略ハ 等シキキ見ル。牛及ビ山羊血清二對シテハ全ク反應七ズ.

以上ノ結果ヨ綜合スルニ，一般二抗乳清血湔八該血清二對シテ極メテ高度二反應スルノ ナラズ, 近緣動物ノ血清ニ對シテモ, 前者二比シテ少シク低度乍ラ明カナル反應き呈ス. 然 レドモ近緣關係相去ル事遠キ動物血清ニ数シテハ全然反應タ認ムル能ハズ. 
宫

川

敬

述

第 2 節 抗かぜいん血清ノ血清二對スル反應

第 4 表 抗牛かぜレん血清ノ各種血清二對スル沈降反應

\begin{tabular}{|c|c|c|c|c|c|c|c|c|c|c|}
\hline $\begin{array}{l}\text { 家鬼 } \\
\text { 番號 }\end{array}$ & 抗 原 & 50 & 100 & 200 & 400 & 800 & 1600 & 3200 & 6400 & 12800 \\
\hline 28 & $\begin{array}{l}\text { 人 血 清 } \\
\text { 牛 血 清 } \\
\text { 山羊血清 } \\
\text { 牛かぜいん }\end{array}$ & $\begin{array}{l}- \\
+ \\
+ \\
+\end{array}$ & $\begin{array}{l}- \\
+ \\
+ \\
+\end{array}$ & $\begin{array}{l}- \\
+ \\
- \\
+\end{array}$ & $\begin{array}{l}- \\
- \\
- \\
+\end{array}$ & $\begin{array}{l}- \\
- \\
- \\
+\end{array}$ & $\begin{array}{l}- \\
- \\
- \\
+\end{array}$ & $\begin{array}{l}- \\
- \\
- \\
+\end{array}$ & $\begin{array}{l}- \\
- \\
- \\
+\end{array}$ & $\begin{array}{l}- \\
- \\
- \\
-\end{array}$ \\
\hline 30 & $\begin{array}{l}\text { 人 血 清 } \\
\text { 牛 血 清 } \\
\text { 山半血清 } \\
\text { 牛かぜいん }\end{array}$ & $\begin{array}{l}- \\
+ \\
+ \\
+\end{array}$ & $\begin{array}{l}- \\
+ \\
\pm \\
+\end{array}$ & $\begin{array}{l}- \\
\pm \\
- \\
+\end{array}$ & $\begin{array}{l}- \\
- \\
- \\
+\end{array}$ & $\begin{array}{l}- \\
- \\
- \\
+\end{array}$ & $\begin{array}{l}- \\
- \\
- \\
+\end{array}$ & $\begin{array}{l}- \\
- \\
- \\
+\end{array}$ & $\begin{array}{l}- \\
- \\
- \\
+\end{array}$ & $\begin{array}{l}- \\
- \\
- \\
-\end{array}$ \\
\hline 31 & $\begin{array}{l}\text { 人 血 清 } \\
\text { 牛 血 清 } \\
\text { 山羊血清 } \\
\text { 牛かぜいん }\end{array}$ & $\begin{array}{l}- \\
+ \\
+ \\
+\end{array}$ & $\begin{array}{l}- \\
+ \\
- \\
+\end{array}$ & $\begin{array}{l}- \\
+ \\
- \\
+\end{array}$ & $\begin{array}{l}- \\
- \\
- \\
+\end{array}$ & $\begin{array}{l}- \\
- \\
- \\
+\end{array}$ & $\begin{array}{l}- \\
- \\
- \\
+\end{array}$ & $\begin{array}{l}- \\
- \\
- \\
+\end{array}$ & $\begin{array}{l}- \\
- \\
- \\
+\end{array}$ & $\begin{array}{l}- \\
- \\
- \\
-\end{array}$ \\
\hline
\end{tabular}

第 4 表. 抗牛かぜいん血清八牛かぜいん二對シテハ 6,400 倍ノ高度二反應スルモ，牛血满 二對シテハ200倍二於テ反應陽性ナルノ $、$ 山羊血清二對シテ八更二低度乍ラ反應 見，人 血清ニ對シテハ全ク陰性ナリ.

第 5 表 抗山羊かぜいん血清ノ各種血清二對スル沈降反應

\begin{tabular}{|c|c|c|c|c|c|c|c|c|c|c|c|}
\hline $\begin{array}{l}\text { 家禹 } \\
\text { 番號 }\end{array}$ & 抗 原 & 50 & 100 & 200 & 400 & 800 & 1600 & 3200 & 6400 & 12800 & 25600 \\
\hline 51 & $\begin{array}{ccc}人 & \text { 血 } & \text { 清 } \\
\text { 牛 } & \text { 血 } & \text { 清 } \\
\text { 山 } & \text { 羊 } & \text { 血 } \\
\text { 清 } \\
\text { 山羊かぜいん }\end{array}$ & $\begin{array}{l}- \\
+ \\
+\end{array}$ & $\begin{array}{l}- \\
- \\
+ \\
+\end{array}$ & $\begin{array}{l}- \\
- \\
\pm \\
+\end{array}$ & $\begin{array}{l}- \\
- \\
-\end{array}$ & $\begin{array}{l}- \\
- \\
-\end{array}$ & $\begin{array}{l}- \\
- \\
- \\
+\end{array}$ & $\begin{array}{l}- \\
- \\
-\end{array}$ & $\begin{array}{l}- \\
- \\
-\end{array}$ & $\begin{array}{l}- \\
- \\
- \\
\pm\end{array}$ & $\begin{array}{l}- \\
- \\
- \\
-\end{array}$ \\
\hline 53 & $\begin{array}{l}\text { 人 血 清 } \\
\text { 牛 血 清 } \\
\text { 山 羊 血 清 } \\
\text { 山羊かぜいん }\end{array}$ & $\begin{array}{l}- \\
+ \\
+ \\
+\end{array}$ & $\begin{array}{l}- \\
- \\
+ \\
+\end{array}$ & $\begin{array}{l}- \\
- \\
+ \\
+\end{array}$ & $\begin{array}{l}- \\
- \\
- \\
+\end{array}$ & $\begin{array}{l}- \\
- \\
- \\
+\end{array}$ & $\begin{array}{l}- \\
- \\
- \\
+\end{array}$ & $\begin{array}{l}- \\
- \\
-\end{array}$ & $\begin{array}{l}- \\
- \\
- \\
+\end{array}$ & $\begin{array}{l}- \\
- \\
- \\
+\end{array}$ & $\begin{array}{l}- \\
- \\
- \\
-\end{array}$ \\
\hline 55 & $\begin{array}{l}\text { 人 血 清 } \\
\text { 牛 血 清 } \\
\text { 山羊 血 清 } \\
\text { !山羊かぜいん }\end{array}$ & $\begin{array}{l}- \\
\pm \\
+ \\
+\end{array}$ & $\begin{array}{l}- \\
- \\
+ \\
+\end{array}$ & $\begin{array}{l}- \\
- \\
\pm \\
+\end{array}$ & $\begin{array}{l}- \\
- \\
-\end{array}$ & $\begin{array}{l}- \\
- \\
- \\
+\end{array}$ & $\begin{array}{l}- \\
- \\
- \\
+\end{array}$ & $\begin{array}{l}- \\
- \\
-\end{array}$ & $\begin{array}{l}- \\
- \\
- \\
+\end{array}$ & $\begin{array}{l}- \\
- \\
- \\
+\end{array}$ & $\begin{array}{l}- \\
- \\
- \\
-\end{array}$ \\
\hline
\end{tabular}

第 5 表. 抗山羊かぜいん血清ハ山羊かぜいんニ對シ。12,800倍ニ於テ反應陽性ナレドモ， 山羊血清二對シテハ僅カニ 200 倍ニ於テ反應ヨ見ル. 牛血清ニ對シテハ更二微弱ナル反應 
呈スルカ或八反應セズ.人血清二對シテハ全ク陰性ナリ.

第 6 表 抗人かぜいん血清, 各種血清二對スル沈降反應

\begin{tabular}{|c|c|c|c|c|c|c|c|c|c|c|}
\hline $\begin{array}{l}\text { 家带: } \\
\text { 番號 }\end{array}$ & 抗 原 & 50 & 100 & 200 & 400 & 800 & 1600 & 3200 & $64: 30$ & 12800 \\
\hline 57 & $\begin{array}{lll}\text { 人 } & \text { 血 } & \text { 清 } \\
\text { 4 } & \text { 血 } & \text { 濇 } \\
\text { 的羊血清 } \\
\text { 人かぜいん }\end{array}$ & $\begin{array}{l}+ \\
- \\
- \\
+\end{array}$ & $\begin{array}{l}- \\
- \\
- \\
+\end{array}$ & $\begin{array}{l}- \\
- \\
- \\
+\end{array}$ & $\begin{array}{l}- \\
- \\
- \\
+\end{array}$ & $\begin{array}{l}- \\
- \\
- \\
+\end{array}$ & $\begin{array}{l}- \\
- \\
-\end{array}$ & $\begin{array}{l}- \\
- \\
-\end{array}$ & $\begin{array}{l}- \\
- \\
- \\
-\end{array}$ & $\begin{array}{l}- \\
- \\
- \\
-\end{array}$ \\
\hline 58 & $\begin{array}{l}\text { 人 血 清 } \\
\text { 牛 血 清 } \\
\text { 山血洏 } \\
\text { 人かぜいん }\end{array}$ & $\begin{array}{l}+ \\
- \\
- \\
+\end{array}$ & $\begin{array}{l}+ \\
- \\
- \\
+\end{array}$ & $\begin{array}{l}- \\
- \\
- \\
+\end{array}$ & $\begin{array}{l}- \\
- \\
- \\
+\end{array}$ & $\begin{array}{l}- \\
- \\
- \\
+\end{array}$ & $\begin{array}{l}- \\
- \\
- \\
+\end{array}$ & $\begin{array}{l}- \\
- \\
-\end{array}$ & $\begin{array}{l}- \\
- \\
- \\
-\end{array}$ & $\begin{array}{l}- \\
- \\
-\end{array}$ \\
\hline 60 & $\begin{array}{l}\text { 人 血 清 } \\
\text { 4 血 清 } \\
\text { 山羊血清 } \\
\text { 人かぜいん }\end{array}$ & $\begin{array}{l}+ \\
- \\
- \\
+\end{array}$ & $\begin{array}{l} \pm \\
- \\
- \\
+\end{array}$ & $\begin{array}{l}- \\
- \\
- \\
+\end{array}$ & $\begin{array}{l}- \\
- \\
- \\
+\end{array}$ & $\begin{array}{l}- \\
- \\
- \\
+\end{array}$ & $\begin{array}{l}- \\
- \\
- \\
\pm\end{array}$ & $\begin{array}{l}- \\
- \\
- \\
-\end{array}$ & $\begin{array}{l}- \\
- \\
-\end{array}$ & $\begin{array}{l}- \\
- \\
-\end{array}$ \\
\hline
\end{tabular}

第 6 表. 抗人かぜいん血清八人かぜいん二對シ 800 倍乃至 1,600 倍二於テ 反應隊性ナレドモ， 人血清二對シテハ 50 倍乃至 100 倍二於テ反應テ見ルノそ．牛及ビ山羊血清二對シテハ全然反 應セズ.

以上ノ成績キ要約スレバ，一般ニ抗かぜレん血清八該血清二對シテ極メテ微弱ナル反應 呈スルノミナラズ，近緣動物血清二對シテ八更二低度ナル反應タ認ム．近親關係相去儿事遠 キ動物血清ニ對シテ八反應七ズ.

第 3 節 抗乳清血清ノ煮沸血淸二對スル反應

第 7 表 抗牛乳清血湔, 爷種煮沸 血潖二對 $九 ル$ 沈降反應

\begin{tabular}{|c|c|c|c|c|c|c|}
\hline 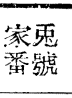 & 抗 原 & 100 & 200 & 400 & 800 & 1600 \\
\hline 33 & 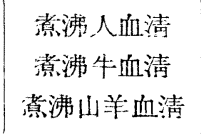 & $\begin{array}{l}? \\
? \\
?\end{array}$ & $\begin{array}{l}- \\
+ \\
-\end{array}$ & $\begin{array}{l}- \\
\pm \\
-\end{array}$ & $\begin{array}{l}- \\
- \\
-\end{array}$ & $\begin{array}{l}- \\
- \\
-\end{array}$ \\
\hline 34 & 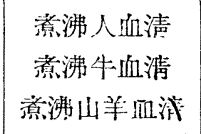 & $\begin{array}{l}? \\
? \\
?\end{array}$ & $\begin{array}{l}- \\
+ \\
+\end{array}$ & $\begin{array}{l}- \\
+ \\
-\end{array}$ & $\begin{array}{l}- \\
- \\
-\end{array}$ & $\begin{array}{l}- \\
- \\
-\end{array}$ \\
\hline 35 & 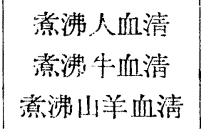 & $\begin{array}{l}? \\
? \\
?\end{array}$ & $\begin{array}{l}- \\
+ \\
\pm\end{array}$ & $\begin{array}{l}- \\
-\end{array}$ & $\begin{array}{l}- \\
- \\
-\end{array}$ & $\begin{array}{l}- \\
- \\
-\end{array}$ \\
\hline
\end{tabular}

新鮮ナル血清习其ノ儘熱沸スル 時八凝固沈澱スル 以テ, 豫 $\times$ 生

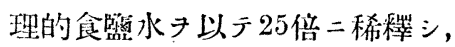
之試驗管二探り嚴重二綿栓习施 シ，更ニソノ上ヨぱらふんん紙二 テ被包シ， $100^{\circ} \mathrm{C}, 30$ 分重湯槊 う加熱ス.

第 7 表. 抗牛乳清血清八竟沸牛 血湭ニ對シテ 200 倍万至 400 倍ノ低 度二於亏反應ス，近總動物，募沸 


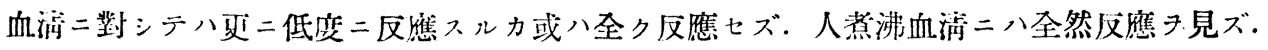

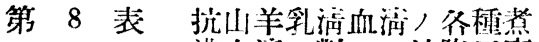
浙血清二對ス儿沈降反㤫

\begin{tabular}{|c|c|c|c|c|c|c|}
\hline $\begin{array}{l}\text { 家饻 } \\
\text { 筷號 }\end{array}$ & 挂 原 & 100 & 200 & 400 & 803 & 1600 \\
\hline \multirow{3}{*}{70} & 㵔沸人血清 & $?$ & - & - & - & - \\
\hline & 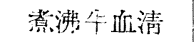 & $?$ & + & - & - & - \\
\hline & 澺沸山羊血清 & $?$ & + & + & - & - \\
\hline \multirow{3}{*}{75} & 溹沸人血婊 & $?$ & - & - & - & - \\
\hline & 湑沸牛细清 & $?$ & \pm & - & - & - \\
\hline & 噫沸川羊血渄 & $?$ & + & + & - & - \\
\hline \multirow{3}{*}{76} & 澺沸人血清 & $?$ & - & - & - & - \\
\hline & 洎沸牛血涌 & $?$ & \pm & - & - & - \\
\hline & 湑沸!!棒血清 & $?$ & + & \pm & - & - \\
\hline
\end{tabular}

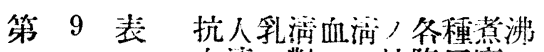
血清二對入ル沈降反應

\begin{tabular}{|c|c|c|c|c|c|c|c|c|}
\hline $\begin{array}{l}\text { 家要 } \\
\text { 䀺號 }\end{array}$ & \begin{tabular}{|l} 
\\
执 原
\end{tabular} & 100 & 200 & 400 & 800 & 1600 & 3200 & 6400 \\
\hline 66 & 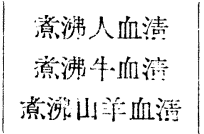 & $\begin{array}{l}? \\
? \\
?\end{array}$ & $\begin{array}{l}+ \\
- \\
-\end{array}$ & $\begin{array}{l}- \\
- \\
-\end{array}$ & $\begin{array}{l}- \\
- \\
-\end{array}$ & $\begin{array}{l}- \\
- \\
-\end{array}$ & $\begin{array}{l}- \\
- \\
-\end{array}$ & $\begin{array}{l}- \\
- \\
-\end{array}$ \\
\hline 67 & 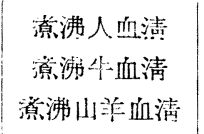 & $\begin{array}{l}? \\
? \\
?\end{array}$ & $\begin{array}{l}+ \\
- \\
-\end{array}$ & $\begin{array}{l}- \\
- \\
-\end{array}$ & $\begin{array}{l}- \\
- \\
-\end{array}$ & $\begin{array}{l}- \\
- \\
-\end{array}$ & $\begin{array}{l}- \\
- \\
-\end{array}$ & $\begin{array}{l}- \\
- \\
-\end{array}$ \\
\hline 69 & 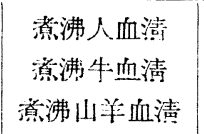 & $\begin{array}{l}? \\
? \\
?\end{array}$ & $\begin{array}{l}+ \\
- \\
-\end{array}$ & $\begin{array}{l}- \\
- \\
-\end{array}$ & - & $\begin{array}{l}- \\
- \\
-\end{array}$ & $\begin{array}{l}- \\
- \\
-\end{array}$ & - \\
\hline
\end{tabular}

第 8 表. 抗山羊乳济血湔八煮沸 川羊血清二低度ナル反應き呈シ，

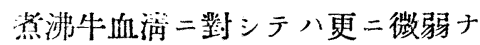
ル反應勺認么。竟沸入血涺二對三 テハ反應セズ.

第 9 表. 抗人乳湆血湔八煮沸人 血清二對シテ低度乍ラ明確二反應

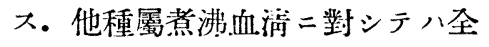
ク反應七ズ.

以上ノ成績 要約スルニ, 一般

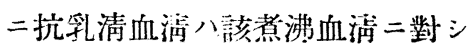
テ低度乍ラ反應 呈 スルノミナラズ, 近 緣動物煮沸血清二對 シテ更二微弱ナル反 應き認又得. 眯緣動. 物煮沸血䇎二對シテ 八反應七ズ.

\section{第 4 節 抗かぜいん血淸ノ煮沸血清二對スル反應}

第 10 表 抗牛かぜいん血清, 各锤煮 劭血湔二對ス儿沈降反應

\begin{tabular}{|c|c|c|c|c|c|}
\hline $\begin{array}{l}\text { 家䅇 } \\
\text { 番號 }\end{array}$ & $\begin{array}{l}\text { 稀釋倍數 } \\
\text { 抗 原 }\end{array}$ & 100 & 200 & 400 & 800 \\
\hline 33 & $\begin{array}{c}\text { 澺沸人血清 } \\
\text { 澺沸牛血清 } \\
\text { 澺沸山羊血挶! }\end{array}$ & $\begin{array}{l}? \\
? \\
?\end{array}$ & $\begin{array}{l}- \\
- \\
-\end{array}$ & $\begin{array}{l}- \\
- \\
-\end{array}$ & $\begin{array}{l}- \\
- \\
-\end{array}$ \\
\hline
\end{tabular}

第 11 表 抗山羊かぜいん血涪ノ各種 並洄血清二對スル沈降反應

\begin{tabular}{|c|c|c|c|c|c|c|}
\hline $\begin{array}{l}\text { 奌息 } \\
\text { 番號 }\end{array}$ & $\begin{array}{l}\text { 稀釋倍數 } \\
\text { 抗 原 }\end{array}$ & 50 & 100 & 200 & 400 & 800 \\
\hline \multirow{3}{*}{51} & 漟沸人血清 & $?$ & $?$ & - & - & - \\
\hline & 㦘沸牛值清 & $?$ & $?$ & - & - & - \\
\hline & 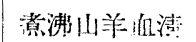 & ? & $?$ & - & - & - \\
\hline
\end{tabular}




\begin{tabular}{|c|c|c|c|c|c|}
\hline 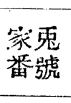 & 抗原 & 100 & 200 & 400 & 800 \\
\hline 34 & $\begin{array}{c}\text { 港沸人血清 } \\
\text { 漟沸牛-血清 } \\
\text { 譩沸山羊血清 }\end{array}$ & $\begin{array}{l}? \\
? \\
?\end{array}$ & $\begin{array}{l}- \\
- \\
-\end{array}$ & $\begin{array}{l}- \\
- \\
-\end{array}$ & $\begin{array}{l}- \\
- \\
-\end{array}$ \\
\hline 35 & 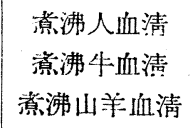 & $\begin{array}{l}? \\
? \\
?\end{array}$ & - & $\begin{array}{l}- \\
- \\
-\end{array}$ & $\begin{array}{l}- \\
- \\
-\end{array}$ \\
\hline
\end{tabular}

第 12 表 抗人かぜんん血汪, 冬種煮 沸血清二對スル沈降反應

\begin{tabular}{|c|c|c|c|c|c|}
\hline 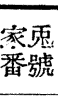 & 抗 原 & 100 & 200 & 400 & 800 \\
\hline \multirow{3}{*}{57} & 煮沸,人血清 & $?$ & - & - & - \\
\hline & 惹沸牛血淸 & $?$ & - & - & - \\
\hline & 若沸山羊血清 & $?$ & - & - & - \\
\hline \multirow{3}{*}{58} & 港沸_人侐清 & $?$ & - & - & - \\
\hline & 澹沸牛血清 & $?$ & - & - & - \\
\hline & 澺沸山羊血嶳 & $?$ & - & - & - \\
\hline \multirow{3}{*}{60} & 漟沸人血清 & $?$ & - & - & - \\
\hline & 煮沸牛血清 & $?$ & - & - & - \\
\hline & 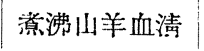 & $?$ & - & - & - \\
\hline
\end{tabular}

\begin{tabular}{|c|c|c|c|c|c|c|}
\hline 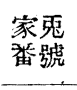 & 抗 原 & 50 & 100 & 200 & 400 & 800 \\
\hline \multirow{3}{*}{53} & 灙沸人血清 & $?$ & ? & - & - & - \\
\hline & 湑沸牛血清 & ? & ? & - & - & - \\
\hline & 漟沸!山华血清 & $?$ & $?$ & - & - & - \\
\hline \multirow{3}{*}{55} & 澺沸人血清 & $?$ & $?$ & - & - & - \\
\hline & 港沸牛血清 & ? & $?$ & - & - & - \\
\hline & 溇沸山羊血清 & $?$ & ? & - & - & - \\
\hline
\end{tabular}

以上ノ成績通覽スルニ,一般二抗か ぜレん血清八煮沸血清二反應セザル事實 $\exists$ 知り得.

\section{第 5 简 本章ノ總括並二考按}

・以上沈降反應二於ケル成績キ總括シテ 考按スル事次ノ如シ。

乳汁习構成スル蛋白質ふらくちお一ん

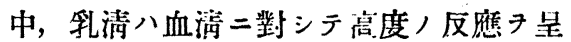
スルニ反シ，かぜレんノ血清二對スル反 應ハ極メテ微弱ナリ。換言スレバ，乳汒・

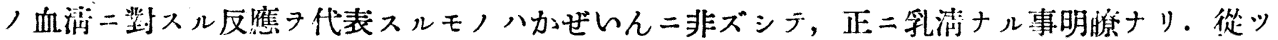
于乳汁蛋白質中血清蛋白質卜近似七几物質八乳潖蛋白質ナリト論斷シ得.

かぜいん，低度乍ラ血清二反應シ得ル事實八，かぜいん，分離不完全ニシテ，乳洋，殘你 二基因スル二非ル無キャノ疑念無キニシモ非ズト踓モ，余八斯カル疑念/起ラン事 顧虑シ,

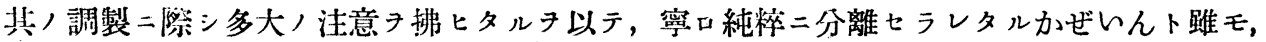

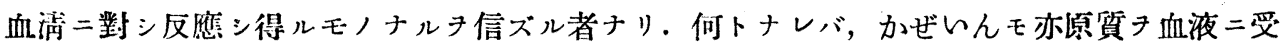

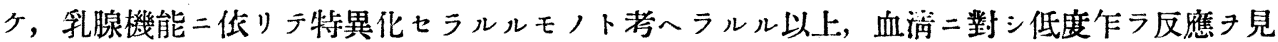
ルトナスモ敢ラ怪シムニ足ラザル可シ. 即チかぜいん並二血清相互間二八特異的受納體ノ外 二微量ノ共通受約體习推知シ得.

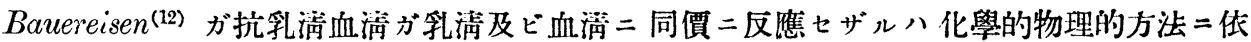

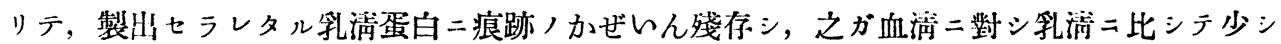
ク低度二反應七シムルニ充分ナル二基クモノナリト述ベシモ，余小かぜいんノ殘存八乳济， 反應二對シテ毫モ障碍卜成ル可キモノニ非ラズト信ズルナ以テ派カ二左袒スル能ハズ. 余八 乳满亚二血清ガ血清學的二强ヒテ同一物質ナリト考フル必要無シト思惟スル者ナリ。 


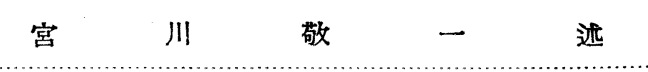

$(191)$

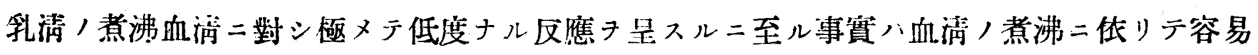
二紮質セシメラルルチ物語ルモノナリ.

\section{第 3 章 補體結合反應試驗二依ル實驗成績 \\ 第 I 節 抗乳清血清八血清:對スル反應}

第 13 表 抗牛乳清血清, 各匭血清二對スル補體結合反應 抗血清20倍

\begin{tabular}{|c|c|c|c|c|c|c|c|c|c|c|}
\hline $\begin{array}{l}\text { 家 更 } \\
\text { 番 號 }\end{array}$ & 抗 原 & 25 & 50 & 100 & 200 & 400 & 800 & 1600 & 3200 & 6400 \\
\hline 33 & $\begin{array}{l}\text { 人 血 清 } \\
\text { 牛 血 清 } \\
\text { 山羊血清 } \\
\text { 生乳 清 }\end{array}$ & $\begin{array}{l}\mathrm{K} \\
\mathrm{fk} \\
\mathrm{K} \\
\mathrm{O}\end{array}$ & $\begin{array}{l}\mathrm{K} \\
\mathrm{fk} \\
\mathrm{K} \\
\mathrm{O}\end{array}$ & $\begin{array}{l}\mathrm{K} \\
\mathrm{fk} \\
\mathrm{K} \\
\mathrm{O}\end{array}$ & $\begin{array}{l}\mathrm{K} \\
\mathrm{K} \\
\mathrm{K} \\
\mathrm{sp}\end{array}$ & $\begin{array}{l}\mathrm{K} \\
\mathrm{K} \\
\mathrm{K} \\
\mathrm{m}\end{array}$ & $\begin{array}{l}\mathrm{K} \\
\mathrm{K} \\
\mathrm{K} \\
\mathrm{m}\end{array}$ & $\begin{array}{l}K \\
K \\
K \\
\text { st }\end{array}$ & $\begin{array}{l}\mathrm{K} \\
\mathrm{K} \\
\mathrm{K} \\
\mathrm{K}\end{array}$ & $\begin{array}{l}\mathrm{K} \\
\mathrm{K} \\
\mathrm{K} \\
\mathrm{K}\end{array}$ \\
\hline 34 & $\begin{array}{l}\text { 人 血 清 } \\
\text { 牛 血 清 } \\
\text { 山羊血清 } \\
\text { 牛乳 清 }\end{array}$ & $\begin{array}{l}\mathrm{K} \\
\mathrm{K} \\
\mathrm{K} \\
\mathrm{O}\end{array}$ & $\begin{array}{l}K \\
K \\
K \\
O\end{array}$ & $\begin{array}{l}K \\
K \\
K \\
O\end{array}$ & $\begin{array}{l}K \\
K \\
K \\
\text { sp }\end{array}$ & $\begin{array}{l}\mathrm{K} \\
\mathrm{K} \\
\mathrm{K} \\
\mathrm{m}\end{array}$ & $\begin{array}{l}K \\
K \\
K \\
\text { fk }\end{array}$ & $\begin{array}{l}\mathrm{K} \\
\mathrm{K} \\
\mathrm{K} \\
\mathrm{K}\end{array}$ & $\begin{array}{l}K \\
K \\
K \\
K\end{array}$ & $\begin{array}{l}\mathrm{K} \\
\mathrm{K} \\
\mathrm{K} \\
\mathrm{K}\end{array}$ \\
\hline 35 & $\begin{array}{l}\text { 人 血 清 } \\
\text { 牛血 清 } \\
\text { 山半血清 } \\
\text { 牛乳 清 }\end{array}$ & $\begin{array}{l}\mathrm{K} \\
\mathrm{fk} \\
\mathrm{K} \\
\mathrm{O}\end{array}$ & $\begin{array}{l}\mathrm{K} \\
\mathrm{fk} \\
\mathrm{K} \\
\mathrm{O}\end{array}$ & $\begin{array}{l}K \\
K \\
K \\
O\end{array}$ & $\begin{array}{l}\mathrm{K} \\
\mathrm{K} \\
\mathrm{K} \\
\mathrm{m}\end{array}$ & $\begin{array}{l}K \\
K \\
K \\
\text { st }\end{array}$ & $\begin{array}{l}K \\
K \\
K \\
\text { fk }\end{array}$ & $\begin{array}{l}K \\
K \\
K \\
K\end{array}$ & $\begin{array}{l}K \\
K \\
K \\
K\end{array}$ & $\begin{array}{l}\mathrm{K} \\
\mathrm{K} \\
\mathrm{K} \\
\mathrm{K}\end{array}$ \\
\hline
\end{tabular}

第13表. 抗牛乳满血垌ハ牛乳清二對シテ僅カ $=100$ 倍二於テ完全溶血阻止き皇スルノ シテ, 牛血清二對シテ極メテ微弱ナル反應タ是スルカ或ハ全っ反應七ズ. 他磒動物血清二對 シテハ全然反應タ認メズ.

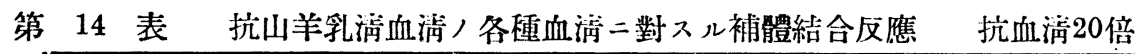

\begin{tabular}{|c|c|c|c|c|c|c|c|c|c|c|}
\hline $\begin{array}{l}\text { 家 秒 } \\
\text { 番 號 }\end{array}$ & 抗 原 & 25 & 50 & 100 & 200 & 400 & 800 & 1600 & 3200 & 6400 \\
\hline 70 & $\begin{array}{l}\text { 人 血 清 } \\
\text { 牛 血 清 } \\
\text { 山羊血清 } \\
\text { 山羊乳清 }\end{array}$ & $\begin{array}{l}\mathrm{K} \\
\mathrm{K} \\
\mathrm{K} \\
\mathrm{O}\end{array}$ & $\begin{array}{l}\mathrm{K} \\
\mathrm{K} \\
\mathrm{K} \\
\mathrm{O}\end{array}$ & $\begin{array}{l}\mathrm{K} \\
\mathrm{K} \\
\mathrm{K} \\
\mathrm{sp}\end{array}$ & $\begin{array}{l}\mathrm{K} \\
\mathrm{K} \\
\mathrm{K} \\
\mathrm{m}\end{array}$ & $\begin{array}{l}\mathrm{K} \\
\mathrm{K} \\
\mathrm{K} \\
\mathrm{m}\end{array}$ & $\begin{array}{l}\mathrm{K} \\
\mathrm{K} \\
\mathrm{K} \\
\mathrm{st}\end{array}$ & $\begin{array}{l}K \\
K \\
K \\
K\end{array}$ & $\begin{array}{l}\mathrm{K} \\
\mathrm{K} \\
\mathrm{K} \\
\mathrm{K}\end{array}$ & $\begin{array}{l}\mathrm{K} \\
\mathrm{K} \\
\mathrm{K} \\
\mathrm{K}\end{array}$ \\
\hline 75 & $\begin{array}{l}\text { 人 血 清 } \\
\text { 血 清 } \\
\text { 山羊血清 } \\
\text { 山羊乳清 }\end{array}$ & $\begin{array}{l}\mathrm{K} \\
\mathrm{K} \\
\mathrm{fk} \\
\mathrm{O}\end{array}$ & $\begin{array}{l}\mathrm{fk} \\
\mathrm{O}\end{array}$ & $\begin{array}{l}\mathrm{K} \\
\mathrm{K} \\
\mathrm{K} \\
\mathrm{O}\end{array}$ & $\begin{array}{l}\mathrm{K} \\
\mathrm{K} \\
\mathrm{K} \\
\mathrm{sp}\end{array}$ & $\begin{array}{l}\mathrm{K} \\
\mathrm{K} \\
\mathrm{K} \\
\mathrm{sp}\end{array}$ & $\begin{array}{l}\mathrm{K} \\
\mathrm{K} \\
\mathrm{K} \\
\mathrm{m}\end{array}$ & $\begin{array}{l}\mathrm{K} \\
\mathrm{K} \\
\mathrm{K} \\
\mathrm{fk}\end{array}$ & $\begin{array}{l}\mathrm{K} \\
\mathrm{K} \\
\mathrm{K} \\
\mathrm{K}\end{array}$ & $\begin{array}{l}\mathrm{K} \\
\mathrm{K} \\
\mathrm{K} \\
\mathrm{K}\end{array}$ \\
\hline 76 & $\begin{array}{l}\text { 人 血 清 } \\
\text { 牛 血 清 } \\
\text { 山羊血清 } \\
\text { !孚清 }\end{array}$ & $\begin{array}{l}\mathrm{K} \\
\mathrm{K} \\
\mathrm{fk} \\
\mathrm{O}\end{array}$ & $\begin{array}{l}\mathrm{K} \\
\mathrm{K} \\
\mathrm{fk} \\
\mathrm{O}\end{array}$ & $\begin{array}{l}\mathrm{K} \\
\mathrm{K} \\
\mathrm{K} \\
\mathrm{m}\end{array}$ & $\begin{array}{l}\mathrm{K} \\
\mathrm{K} \\
\mathrm{K} \\
\mathrm{st}\end{array}$ & $\begin{array}{l}K \\
K \\
K \\
\text { fk }\end{array}$ & $\begin{array}{l}\mathrm{K} \\
\mathrm{K} \\
\mathrm{K} \\
\mathrm{K}\end{array}$ & $\begin{array}{l}\mathrm{K} \\
\mathrm{K} \\
\mathrm{K} \\
\mathrm{K}\end{array}$ & $\begin{array}{l}\mathrm{K} \\
\mathrm{K} \\
\mathrm{K} \\
\mathrm{K}\end{array}$ & $\begin{array}{l}\mathrm{K} \\
\mathrm{K} \\
\mathrm{K} \\
\mathrm{K}\end{array}$ \\
\hline
\end{tabular}




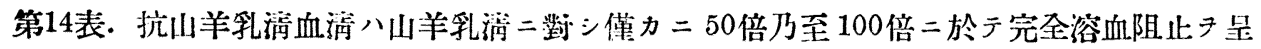

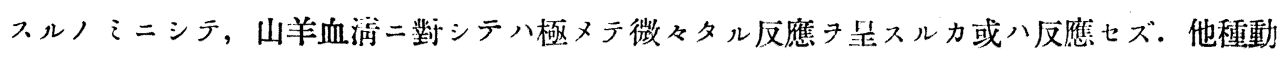
物血湔ニ對シテハ全ク反應セズ.

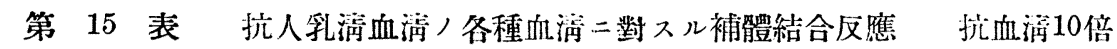

\begin{tabular}{|c|c|c|c|c|c|c|c|c|c|c|c|}
\hline 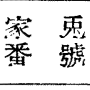 & $\begin{array}{ll} & \text { 稀釋倍數 } \\
\text { 抗 原 }\end{array}$ & 25 & 50 & 100 & 200 & 400 & 850 & 1600 & 3200 & 6400 & 12800 \\
\hline \multirow{4}{*}{66} & 人 血 清 & $\mathrm{sp}$ & $\mathrm{m}$ & m & st & K & K & K & K & K & K \\
\hline & 牛 血 清 & $\mathrm{K}$ & $\mathrm{K}$ & $\mathrm{K}$ & K & K & $\mathrm{K}$ & $\mathrm{K}$ & $\mathrm{K}$ & $\mathrm{K}$ & $\mathrm{K}$ \\
\hline & !羊监清 & K & K & K & K & $\mathrm{K}$ & K & K & K & K & K \\
\hline & 人 乳 清 & 0 & 0 & 0 & O & 0 & 0 & sp & $\mathrm{m}$ & K & K \\
\hline \multirow{4}{*}{67} & 人 血 清 & $\mathrm{K}$ & K & $\mathrm{K}$ & $\mathrm{fk}$ & st & $\mathrm{m}$ & K & $\mathrm{K}$ & K & K \\
\hline & 牛 血 犕 & $\mathrm{K}$ & K & K & $\mathrm{K}$ & K & K & K & K & $\mathrm{K}$ & $\mathrm{K}$ \\
\hline & 川羊血湍 & $\mathrm{K}$ & K & $\mathrm{K}$ & $\mathrm{K}$ & $\mathrm{K}$ & K & $\mathrm{K}$ & $\mathrm{K}$ & $\mathrm{K}$ & $\mathrm{K}$ \\
\hline & 人 乳 清 & 0 & o & o & O & 0 & 0 & $\mathrm{sp}$ & $\mathrm{sp}$ & st & $\mathrm{fk}$ \\
\hline \multirow{4}{*}{69} & 人 血i 清 & $\mathrm{m}$ & m & st & st & $\mathrm{fk}$ & $\mathrm{K}$ & $\mathrm{K}$ & K. & $\mathrm{K}$ & K \\
\hline & 牛 血 清 & K & K & K & $\mathrm{K}$ & $\mathrm{K}$ & K & $\mathrm{K}$ & $\mathrm{K}$ & K & K \\
\hline & 山羊血㽟 & $\mathrm{K}$ & $\mathrm{K}$ & K & K & $\mathrm{K}$ & $\mathrm{K}$ & $\mathrm{K}$ & $\mathrm{K}$ & K & $\mathrm{K}$ \\
\hline & 人 钝 清 & 0 & 0 & 0 & 0 & 0 & spch & $\mathrm{sp}$ & $\mathrm{m}$ & $\mathrm{fk}$ & K \\
\hline
\end{tabular}

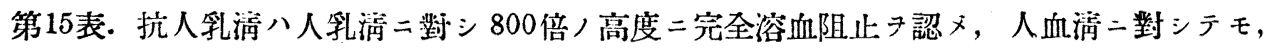

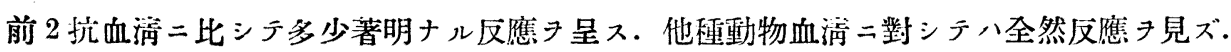

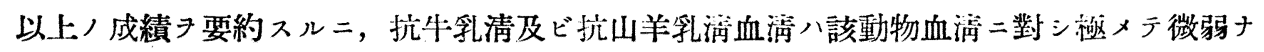

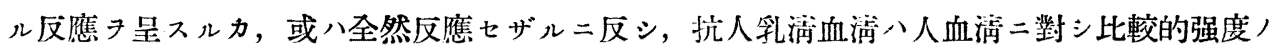
反應タ認ム。

第 2 節 抗かぜいん血清ノ血清二對スル反應

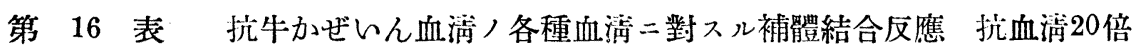

\begin{tabular}{|c|c|c|c|c|c|c|c|c|c|c|c|}
\hline 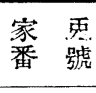 & 抗 原 & 25 & 50 & 100 & 200 & 400 & 800 & 1600 & 3200 & 6403 & 12800 \\
\hline \multirow{4}{*}{28} & 人 佔 清 & $\mathrm{K}$ & K & K & K & K & $\mathrm{K}$ & $\mathrm{K}$ & $\mathrm{K}$ & $\mathrm{K}$ & K \\
\hline & 牛 血 清 & $\mathrm{fk}$ & K & $\mathrm{K}$ & $\mathrm{K}$ & $\mathrm{K}$ & $\mathrm{K}$ & $\mathrm{K}$ & K & $\mathrm{K}$ & $\mathrm{K}$ \\
\hline & 山! 羊皿清 & K & K & $\mathrm{K}$ & $\mathrm{K}$ & $\mathrm{K}$ & $\mathrm{K}$ & K & is & $\mathrm{K}$ & $\mathrm{K}$ \\
\hline & 牛か:ぜいん， & 0 & O & 0 & 0 & 0 & 0 & O & O & spch & spch \\
\hline \multirow{4}{*}{30} & 人 血 清 & K & K & K & K & K & K & $\mathrm{K}$ & $\mathrm{K}$ & K & $\mathrm{K}$ \\
\hline & 牛 血 清 & K & K & $K$ & K & K & K & K & K & K & K \\
\hline & 山羊衈镥 & K & K & K & $\mathrm{K}$ & $\mathrm{K}$ & $\mathrm{K}$ & $\mathrm{K}$ & $\mathrm{K}$ & $\mathrm{K}$ & $\mathrm{K}$ \\
\hline & 牛かぜいん & 0 & o & 0 & 0 & o & 0 & sp & $\mathrm{m}$ & $\mathrm{m}$ & $\mathrm{K}$ \\
\hline
\end{tabular}




\begin{tabular}{|c|c|c|c|c|c|c|c|c|c|c|c|}
\hline $\begin{array}{l}\text { 家 鬼 } \\
\text { 舀 號 }\end{array}$ & 抗 原 & 25 & 50 & 100 & 200 & 400 & 890 & 1600 & 3200 & 6400 & 12800 \\
\hline \multirow{4}{*}{31} & 人血濾 & $\mathrm{K}$ & $\mathrm{K}$ & $\mathrm{K}$ & $\mathrm{K}$ & K & $\mathrm{K}$ & $\mathrm{K}$ & $\mathrm{K}$ & $\mathrm{K}$ & $\mathrm{K}$ \\
\hline & 坐 血 清 & K & $\mathrm{K}$ & $\mathrm{K}$ & $\mathrm{K}$ & $\mathrm{K}$ & K & $\mathrm{K}$ & $\mathrm{K}$ & $\mathrm{K}$ & $\mathrm{K}$ \\
\hline & 山羊血清 & $\mathrm{K}$ & $\mathrm{K}$ & $\mathrm{K}$ & $\mathrm{K}$ & K & K & K & $\mathrm{K}$ & $\mathrm{K}$ & $\mathrm{K}$ \\
\hline & 牛かや゙いん & 0 & 0 & $\mathrm{O}$ & O & O & 0 & sp & m & $\mathbf{m}$ & $\mathrm{fk}$ \\
\hline
\end{tabular}

第16表. 抗牛かぜいん血清八，牛かぜいん二對シ極メラ高度ノ反應フ呈スルニモ拘ラズ，

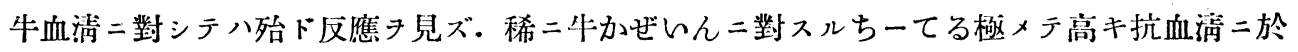
テ極メテ微弱ナ反應习認ムル事アリ. 他種動物血温二對シテハ全然反應セズ.

第 17 表 抗山羊かぜいん血清ノ各種血清二對スル補體結合反應 抗血清20倍

\begin{tabular}{|c|c|c|c|c|c|c|c|c|c|c|c|}
\hline $\begin{aligned} & \text { 塚 } \text { 雷 } \\
&\end{aligned}$ & 抗 原 & 25 & 50 & 100 & 200 & 400 & 800 & 1600 & 3200 & 64.00 & 12800 \\
\hline \multirow{4}{*}{51} & 人 血 濇 & $\mathrm{K}$ & $\mathrm{K}$ & $\mathrm{K}$ & $\mathrm{K}$ & K & $\mathrm{K}$ & $\mathrm{K}$ & $\mathrm{K}$ & K & $\mathrm{K}$ \\
\hline & 牛 血 清 & K & K & K & $\mathrm{K}$ & $\mathrm{K}$ & $\mathrm{K}$ & $\mathrm{K}$ & K & K & K \\
\hline & !羊血清 & $\mathrm{K}$ & $\mathrm{K}$ & $\mathrm{K}$ & K & $\mathrm{K}$ & K & K & K & $\mathrm{K}$ & $\mathrm{K}$ \\
\hline & 山羊かぜいん & 0 & O & O & $O$ & $\mathrm{sp}$ & $\mathbf{m}$ & $\mathrm{m}$ & $\mathrm{fk}$ & K & K \\
\hline \multirow{4}{*}{53} & 人 血 清 & $\mathrm{K}$ & K & $\mathrm{K}$ & $\mathrm{K}$ & $\mathrm{K}$ & $\mathrm{K}$ & K & K & $\mathrm{K}$ & K \\
\hline & 牛 血 清 & K & K & $\mathrm{K}$ & $\mathrm{K}$ & $\mathrm{K}$ & K & K & $\mathrm{K}$ & $\mathrm{K}$ & K \\
\hline & 山羊血清 & $\mathrm{fk}$ & $\mathrm{K}$ & K & K & $\mathrm{K}$ & K & K & $\mathrm{K}$ & K & $\mathrm{K}$ \\
\hline & 山羊かぜいん & O & O & O & o & O & O & O & 0 & O & O \\
\hline \multirow{4}{*}{55} & 人 血 濇 & $\mathrm{K}$ & $\mathrm{K}$ & K & $\mathrm{K}$ & K & K & K & $\mathrm{K}$ & K & K \\
\hline & 牛 血 清 & $\mathrm{K}$ & $\mathrm{K}$ & $\mathrm{K}$ & K & $\mathrm{K}$ & $\mathrm{K}$ & $\mathrm{K}$ & K & $\mathrm{K}$ & $\mathrm{K}$ \\
\hline & 山羊血清 & $\mathrm{fk}$ & $\mathrm{fk}$ & $\mathrm{K}$ & K & $\mathrm{K}$ & $\mathrm{K}$ & K & $\mathrm{K}$ & $\mathrm{K}$ & $\mathrm{K}$ \\
\hline & 山羊かぜいん & O & O & 0 & 0 & o & $\mathrm{O}$ & 0 & o & o & o \\
\hline
\end{tabular}

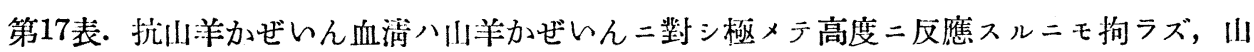
羊血清二對シテハ極メテ微くタル反應キ呈スルカ或ハ全然反應七ズ。他種動物血清二對シテ 反應き呈セズ.

第 18 表抗人かぜいん血琵ノ各種血埇二對スル補體結合反應

\begin{tabular}{|c|c|c|c|c|c|c|c|c|}
\hline $\begin{array}{ll}\text { 家 } & \text { 戛 } \\
\text { 號 }\end{array}$ & 抗 原 & 25 & 50 & 100 & 200 & 400 & 800 & 1600 \\
\hline \multirow{4}{*}{57} & 人 血 清 & K & $\mathrm{K}$ & K & K & $\mathrm{K}$ & K & $\mathrm{K}$ \\
\hline & 牛 血 清 & $\mathrm{K}$ & $\mathrm{K}$ & K & K & K & K & $\mathrm{K}$ \\
\hline & 山羊血清 & K & $\mathrm{K}$ & $\mathrm{K}$ & K & K & K & K \\
\hline & 人かぜいタ & 0 & O & 0 & $\mathrm{sp}$ & $\mathrm{m}$ & m & $\mathrm{m}$ \\
\hline \multirow{4}{*}{58} & 人 血 清 & $\mathrm{K}$ & $\mathrm{K}$ & $\mathrm{K}$ & K & $\mathrm{K}$ & K & K \\
\hline & 牛 血 清 & K & K & K & K & $\mathrm{K}$ & K & $\mathrm{K}$ \\
\hline & 山羊血清 & $\mathrm{K}$ & K & K & $\mathrm{K}$ & $\mathrm{K}$ & K & K \\
\hline & 人かぜいん & 0 & O & 0 & 0 & sp & $\mathrm{sp}$ & $\mathrm{fk}$ \\
\hline
\end{tabular}




\begin{tabular}{|c|c|c|c|c|c|c|c|c|}
\hline $\begin{array}{l}\text { 家 桑 } \\
\text { 番 號 }\end{array}$ & 抗 原 & 25 & 50 & 100 & 200 & 400 & 800 & 1600 \\
\hline \multirow{4}{*}{60} & 人 血 清 & $\mathrm{K}$ & K & $\mathrm{K}$ & $\mathrm{K}$ & $\mathrm{K}$ & $\mathrm{K}$ & K \\
\hline & 牛 血 清 & $\mathrm{K}$ & K & K & K & K & $\mathrm{K}$ & K \\
\hline & 山羊血清 & $\mathrm{K}$ & $\mathrm{K}$ & $\mathrm{K}$ & $\mathrm{K}$ & $\mathrm{K}$ & $\mathrm{K}$ & $\mathrm{K}$ \\
\hline & 人がぜいん & 0 & o & O & o & $\mathrm{sp}$ & m & $\mathrm{K}$ \\
\hline
\end{tabular}

第18表. 抗人かぜんん血清八人かぜいん二對シテ比較的低度二反應陽性二シテ，人血清及 ビ他種屬血垌二對シテハ全ク反應 見ズ.

以上ノ結果要約スレバ，一般二抗かぜレん血清ハ血清二反應セズ. 但シちーてる極メテ 高キ洔ハ屚タ極メテ微弱ナル反應き見ル。

第 3 節 抗乳淸血清ノ募沸血清二對スル反應

第 19 表 抗牛乳漓血清, 各種募沸血朔二對ス几補體結合反應抗血清20倍

\begin{tabular}{|c|c|c|c|c|c|c|c|}
\hline $\begin{array}{ll}\text { 家 } & \text { 霆 } \\
\text { 番 }\end{array}$ & 抗 原 & 25 & 50 & 100 & 200 & 400 & 800 \\
\hline \multirow{3}{*}{33} & 港沸人血清 & $\mathrm{K}$ & $\mathrm{K}$ & $\mathrm{K}$ & $\mathrm{K}$ & $\mathrm{K}$ & $\mathrm{K}$ \\
\hline & 港沸牛血声 & K & K & K & K & K & K \\
\hline & 港沸山羊血声 & K & K & K & K & K & K \\
\hline \multirow{3}{*}{35} & 漟沸人血淸 & K & $\mathrm{K}$ & K & $\mathrm{K}$ & $\mathrm{K}$ & $\mathrm{K}$ \\
\hline & 漟沸牛血清 & $\mathrm{K}$ & $\mathrm{K}$ & K & $\mathrm{K}$ & $\mathrm{K}$ & $\mathrm{K}$ \\
\hline & 潦沸山羊血清 & $\mathrm{K}$ & K & K & $\mathrm{K}$ & $\mathrm{K}$ & $\mathrm{K}$ \\
\hline
\end{tabular}

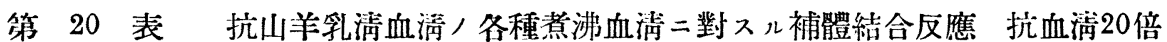

\begin{tabular}{|c|c|c|c|c|c|c|c|}
\hline 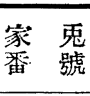 & 抗 原 & 25 & 50 & 100 & 200 & 400 & 800 \\
\hline \multirow{3}{*}{70} & 潦沸人血清 & $\mathrm{K}$ & K & K & K & K & K \\
\hline & 黨沸牛血清 & K & K & K & $\mathrm{K}$ & K & K \\
\hline & 漟沸山羊血清 & K & K & K & K & K & $\mathrm{K}$ \\
\hline \multirow{3}{*}{76} & 港沸人血瑇 & K & K & $\mathrm{K}$ & K & K & $\mathrm{K}$ \\
\hline & 潦沸牛血清 & K & $\mathrm{K}$ & $\mathrm{K}$ & $\mathrm{K}$ & K & $\mathrm{K}$ \\
\hline & 咸沸山羊血清 & $\mathrm{K}$ & $\mathrm{K}$ & $\mathrm{K}$ & K & $\mathrm{K}$ & $\mathrm{K}$ \\
\hline
\end{tabular}

第 21 表 抗人乳清血垌/各種煮沸血清二對入儿補體結合反應 抗血淸10倍

\begin{tabular}{|c|c|c|c|c|c|c|c|}
\hline $\begin{array}{ll}\text { 家 } & \text { 廆 } \\
\text { 番 } & \text { 號 } \\
\end{array}$ & 抗 原 & 25 & 50 & 100 & 200 & 400 & 800 \\
\hline \multirow{3}{*}{66} & 㵭沸人血清 & $\mathrm{fk}$ & fk & $\mathrm{fk}$ & K & $\mathrm{K}$ & $\mathrm{K}$ \\
\hline & 潦沸牛血清 & $\mathrm{K}$ & K & $\mathrm{K}$ & $\mathrm{K}$ & $\mathrm{K}$ & K \\
\hline & 滰沸山羊血清 & K & K & K & K & $\mathrm{K}$ & $\mathrm{K}$ \\
\hline
\end{tabular}


宮川敬紧述

\begin{tabular}{|c|c|c|c|c|c|c|c|}
\hline $\begin{array}{l}\text { 家 免 } \\
\text { 番 號 } \\
\end{array}$ & 抗 原 & 25 & 50 & 100 & 200 & 400 & 800 \\
\hline \multirow{3}{*}{67} & 渼沸人血清 & $\mathrm{fk}$ & $\mathrm{K}$ & $\mathrm{K}$ & $\mathrm{K}$ & $\mathrm{K}$ & $\mathrm{K}$ \\
\hline & 潦沸牛血清 & $\mathrm{K}$ & $\mathrm{K}$ & $\mathrm{K}$ & $\mathrm{K}$ & $\mathrm{K}$ & $\mathrm{K}$ \\
\hline & 漟沸山羊血清 & $\mathrm{K}$ & $\mathrm{K}$ & $\mathrm{K}$ & $\mathrm{K}$ & $\mathrm{K}$ & $\mathrm{K}$ \\
\hline
\end{tabular}

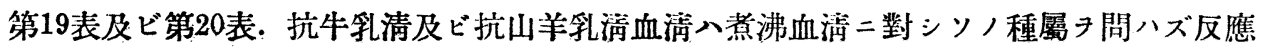
ヨ呈セズ.

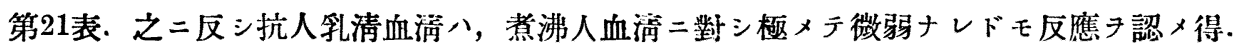
他理屬煮沸血清二對シテハ全ク反應セズ.

第 4 帴抗かぜいん血清ノ煮沸血清二對スル反應

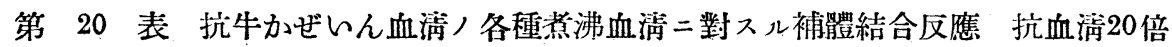

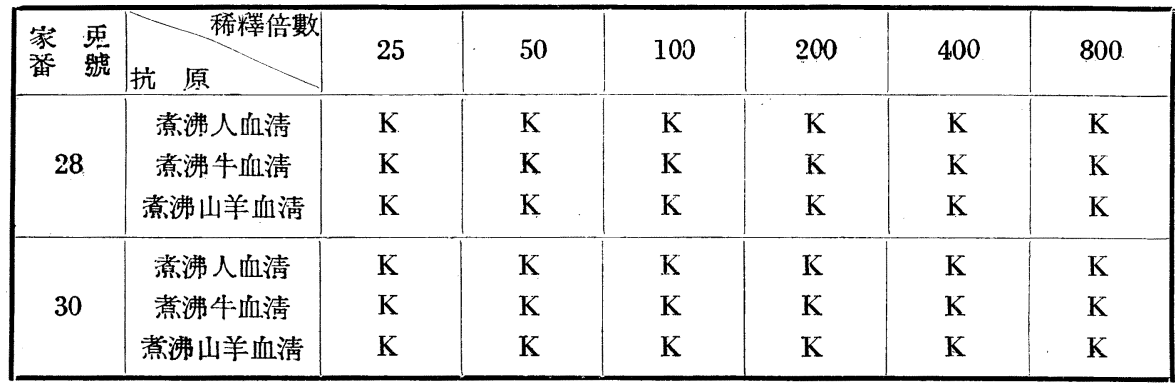

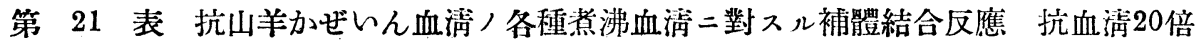

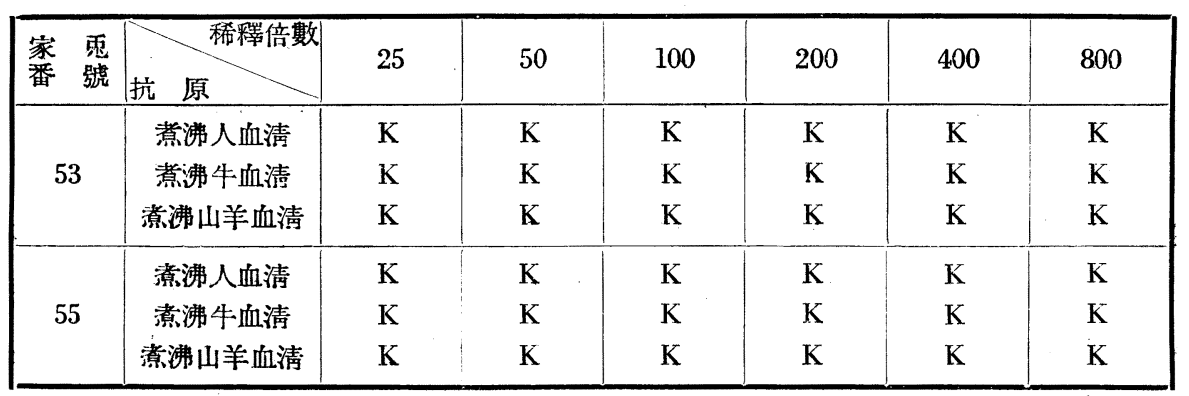

第 22 表 抗人かぜいん血清ノ各種煮沸血清二對入儿補體結合反應 抗血清10倍

\begin{tabular}{|c|c|c|c|c|c|c|c|}
\hline $\begin{array}{l}\text { 家 鬼 } \\
\text { 番 號 }\end{array}$ & 抗 原 & 25 & 50 & 100 & 200 & 400 & 800 \\
\hline \multirow{3}{*}{57} & 潦沸人血清 & K & K & K & $\mathrm{K}$ & K & $\mathrm{K}$ \\
\hline & 意沸牛血清 & K & $\mathrm{K}$ & $\mathrm{K}$ & $\mathrm{K}$ & $\mathrm{K}$ & $\mathrm{K}$ \\
\hline & 漟沸山羊面清 & $\mathrm{K}$ & $\mathrm{K}$ & $\mathrm{K}$ & $\mathrm{K}$ & $\mathrm{K}$ & $\mathrm{K}$ \\
\hline
\end{tabular}




\begin{tabular}{|c|c|c|c|c|c|c|c|}
\hline $\begin{array}{ll}\text { 家 鬼 } \\
\text { 番 號 }\end{array}$ & 抗 原 & 25 & 50 & 100 & 200 & 400 & 800 \\
\hline \multirow{3}{*}{58} & 潦沸人血清 & K & $\mathrm{K}$ & $\mathrm{K}$ & K & K & $\mathrm{K}$ \\
\hline & 潦沸牛血清 & $\mathrm{K}$ & K & $\mathrm{K}$ & $\mathrm{K}$ & $\mathrm{K}$ & K \\
\hline & 漟沸山羊血清 & K & K & $\mathrm{K}$ & K & K & $\mathrm{K}$ \\
\hline
\end{tabular}

以上ノ成績 通覽スルニ，一般二抗かぜレん血清ハ煮沸血满ニ對シテ反應セズ.

\section{第 5 第本章ノ總括並二考按}

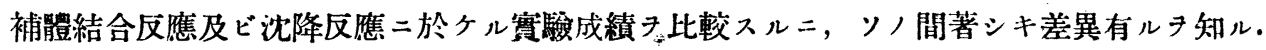
即于沈降反應二於テ，牛及ビ山羊乳清八該動物血活二對シ高度ノ反應カキ有スルニモ拘ラズ, 補體結合反應二於テ・極メテ微弱ナル反應キ呈スルカ, 或八反應タ認ィズ. 但シ人乳清ノ々 八例外二シテ，補體結合反應二於テモ人血清二對シ比較的著明ナル反應 呈ス．然ラバ，斯 クノ如ク沈降反應及ビ補體結合反應二於テ矛盾セル成績キ得ルハ如何ナル理由二基クモノナ リヤ. 今少シク考察习加ヘント欲ス. 抑々牛及ビ山羊乳汒蛋白質ふらく古お一んノ苼疫血清 タル抗乳清並二抗かぜいん血清八共二高價ナル沈降素トシテ作用スルニ反シ, 補體結合性抗

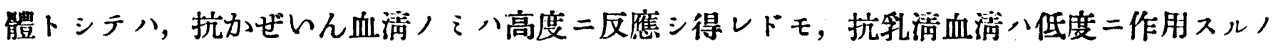
i . 依ツテ余八家鬼二對スル牛及ビ山羊乳清ノ注射量並二回數テ增加シテ 6 回, 全乳ノ絕對 量二於テ $20 \mathrm{~g}$. 二及ビタルモ，殆ド抗乳满血涪ノ補體結合性抗體價 上上昇セシムル事能ハ少 リキ. 換言スレバ一般ニ牛及ビ川羊乳活八補體結合性抗體產生能力八極メテ低キ事實す知ル ア得タリ. 斯クシテ沈降反應二於テ抗乳清血清八乳满二對シテ高度ナル反應タ呈スルノミナ ラズ，乳湔二近似蛋白質ナル血活二数シテモ高度二反應シ得. 之二反シテ補體結合反應二於 テハ, 乳满二對シテスラ低度ナル反應 呈スルノ スルモ敢テ怪シムニ足ラザル可シ。

然ルニ人乳蛋白質ふらくちおーんニ在りテハ，上述セシ牛及ビ山羊乳蛋白質ふらくちお一 んノ場合卜相異り, 沈降反應及ビ補體結合反應ノ何レニ於テモ, 抗乳㵝血清ノ抗體價八抗か

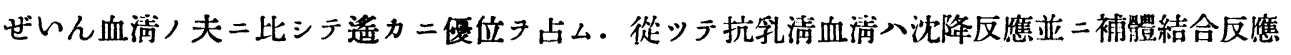

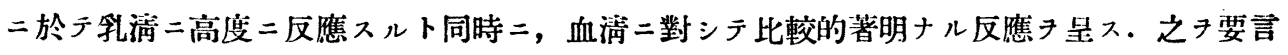
スレバ, 沈降反應及ビ補體結合反應二於テ同一抗乳清血清/血清二對スル反應二著明ナル差 異习生ズルハ, 兩反應二於ケル該免疫血清ノ抗體價二高低アルキ以テナリ.

かぜいん八一般二血活二對シテ反應七ザルカ, 或八反應スルモ極メテ微弱ナル八沈降反應 二於ヶルト略々同樣ナリ．斯ル事實ハかぜいんノ血清蛋白質ト極メテ相異ナル蛋白質ナルキ 表示スルモノニシテ，かぜいんノ乳腺機能二依リテ特異化セラルル蛋白質ナル事キ推知セシ 
ムルモノナリ.

乳谪及ビかぜレん八補體結命反應二於デ，一般二募沸血湔二反應七ズ.

\section{結㻅}

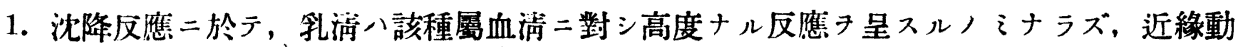

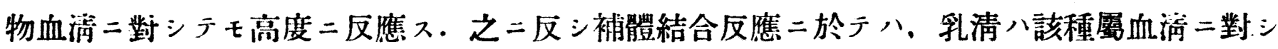

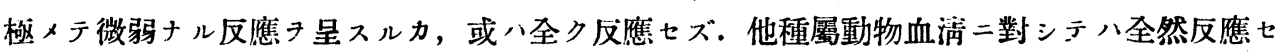
ズ. 兩反應二於ケル斯クノ如キ差異ハ, 抗乳活血清ノ乳溔二對スル沈降素ハ極メテ高價ナル 二反シ, 補體結合性抗澧ガ低價ナル二基因スルモノニシテ, 乳清卜血清卜ノ近親關係テ知ル 二八補體結合反應ヨリ八沈降反應 キ以テ優レタリトス．沈降反應ニヨリテ兩者ノ近似性 推 知三得.

2. かぜいんハ一般二沈降反應二於テ，血清二對シ低度乍ラ反應キ見ルニ反シ，補體結合 反應二於テハ反應ヨ呈セズ. 但シ抗血清ノちーてる高キ場合二八稀二極メテ微弱ナル反應 示ス事アリ。

3. 沈降反應二於テ，乳清八煮沸血清二對シ低度乍ラ反應ヲ呈スレトモ，補體結合反應二 於テハ，全ク反應陰性ナリ。

4. かぜレん八兩反應キ通ジテ，募沸血清二反應セズ.

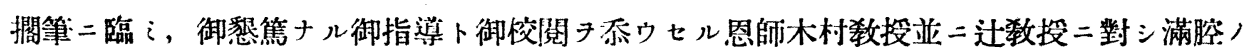
感謝 キ捧グ.

(文 献 後 出) 